\title{
1. INTRODUCTION TO LEG 145: NORTH PACIFIC TRANSECT ${ }^{1}$
}

\author{
Shipboard Scientific Party ${ }^{2}$
}

\section{PALEOCEANOGRAPHIC SETTING}

Subarctic Pacific Ocean sediments contain a critical record of late Mesozoic and Cenozoic oceanographic and climatic changes: however, existing sites are too few and generally too disturbed by rotary drilling to permit detailed reconstructions. The region therefore represents a significant gap in our knowledge of the evolution of Earth's ocean and climate systems. This area extends over $35 \times 10^{6} \mathrm{~km}^{2}$ and includes two major boundary currents (the Oyashio and Alaskan currents), and an oceanic and atmospheric frontal zone (the Subarctic Front), which is thought to have migrated over several degrees of latitude on both short and long time scales. Passes through the Aleutian and Kuril arcs provide exchange sites for deep waters, which exert a strong influence upon the properties of North Pacific Intermediate Water. The area is a source of both heat and moisture for the North American continent and is one of the most biologically productive areas of the world oceans.

At present, the North Pacific Ocean is the terminus of the deepocean circulation route originating in the northern North Atlantic and the Southern oceans and the beginning of the return surface circulation. These old, deep waters are nutrient-rich, oxygen-poor, and highly corrosive to calcium carbonate. Recent evidence suggests that at various times during the Quaternary, calcite preservation was better in both the deep northeastern and northwestern Pacific Ocean (Keigwin, 1987: Keigwin et al., 1992; Zahn et al., 1991; Hovan et al., 1991), but it is not clear to what extent these and other changes reflect those in deepocean circulation, as opposed to changes in local depositional conditions.

Work in other regions of the world has defined a series of events or rapid changes in ocean circulation and global climate during Neogene time. These include the middle and latest Miocene, thought to be times of expansion of Antarctic Ocean glaciers (Woodruff et al., 1981; Savin et al., 1981; Kennett, 1986), the late Pliocene growth of ice in the Northern Hemisphere (Shackleton et al., 1984; Rea and Schrader. 1985), and the more recent increase in the amplitudes of Northern Hemisphere glaciation during the middle Pleistocene (Ruddiman et al., 1989). The longer-term changes appear to have been superimposed upon ongoing, higher-frequency variability cycles at roughly Milankovitch periods. The effect of these changes upon the North Pacific Ocean is largely unknown, given the small number of previous sites and the general absence of calcareous sediments therein. Strategic location of drilling sites within the North Pacific subpolar gyre, situated upon oceanic highs and in the deep basins, will permit the generation of latitudinal, longitudinal, and depth transects to complete the global picture of climate and circulation throughout the Neogene.

Limited recovery from North Pacific and Bering Sea COST wells suggests that regional sedimentation during the Eocene and early Oligocene was calcareous; this was followed by a period of pelagic clay deposition until middle Miocene time, when siliceous sediments began to accumulate throughout the region (Keller and Barron, 1983). The timing and rate of decreased calcareous production are not known;

'Rea. D.K., Basov, 1.A.. Janecek, T.R., Palmer-Julson. A.. et al., 1993, Proc, ODP, Init. Repts., 145: College Station, TX (Ocean Drilling Program).

${ }^{2}$ Shipboard Scientific Party is as presented in list of participants preceding the contents. siliceous sediments appeared abruptly between 14 and $15 \mathrm{Ma}$. While plate migration may account for a portion of this trend, it does not explain several elements: the occurrence of in-situ calcareous sedimentation in the Bering Sea and the rapidity and apparent synchroneity of appearance in the siliceous sediments throughout the North Pacific. The evidence implies a change in regional circulation and productivity from a mid-Paleogene ocean, which was warm, stratified, and had net downward transport (like the North Atlantic today), to a mid-Neogene ocean, which was cool and well mixed, and had net upward transport (Woodruff and Savin, 1989). Such a change would probably have affected nutrient concentrations downstream, leading to lower silica production in the Atlantic and Indian oceans, and may signal a change in atmospheric circulation and climate. However, the number and locations of existing North Pacific sites are such that considerable doubt remains concerning the extent of this change; most of the sites lie near the continents and may reflect changes in boundary currents, rather than in the open gyre. Drilling sites within the subpolar gyre will permit an assessment of regional changes in the mass accumulation rate of silica during the Cenozoic.

Atmospheric circulation and its link to sea-surface circulation and biological productivity are important components of climatic change. Much of our understanding of these aspects of climate change have come from three North Pacific cores (Janecek and Rea, 1983; Rea et al., 1985; Janecek, 1985). These cores generally are of low biostratigraphic resolution, and all are sited along about the same latitude, precluding any understanding of latitudinal variation in the global wind system. Sites located to increase the latitudinal span of eolian records will permit (1) enhanced definition of any changes in atmospheric circulation associated with the Cretaceous/Tertiary boundary; (2) an evaluation of the latitudinal variability of the known large change in atmospheric circulation associated with the Paleocene/ Eocene boundary (important for comparison to computer models of climate change); (3) a test of the suggestion that enhanced Northern Hemisphere atmospheric circulation and concomitant biological productivity were directly responsible for the onset of massive silica sedimentation in the Miocene; and (4) documentation of changes in atmospheric circulation associated with the Pliocene onset of Northern Hemisphere glaciation.

Pelagic clays are reliable recorders of ocean paleochemistry; signals reflecting terrigenous influx, seafloor hydrothermal activity, volcanism, biological activity, authigenesis, bollide impacts, etc., are captured by these clays. Prior work in the North Pacific has shown the presence of the Ir anomaly associated with the Cretaceous/Tertiary boundary (Kyte and Wasson, 1986) and the influx of hydrothermal components associated with the earliest Eocene plate-boundary rearrangements (Owen and Rea, 1985; Leinen, 1987, 1989; Rea et al., 1990). Drilling during Leg 145 was expected to recover all these signals, along with the geochemical signal associated with the plate boundary reorganization that occurred during the Late Cretaceous magnetic quiet zone. The rifting episode that resulted in the formation of the Chinook Trough in the central North Pacific is part of this event (Rea and Dixon, 1983), and proposed Site NW4A, just south of the trough on somewhat older crust, was expected to provide a clear, proximal geochemical record of intraplate rifting.

During the middle and later parts of the Cretaceous, the IndoPacific was one broad global ocean. Not much of the paleoceano- 


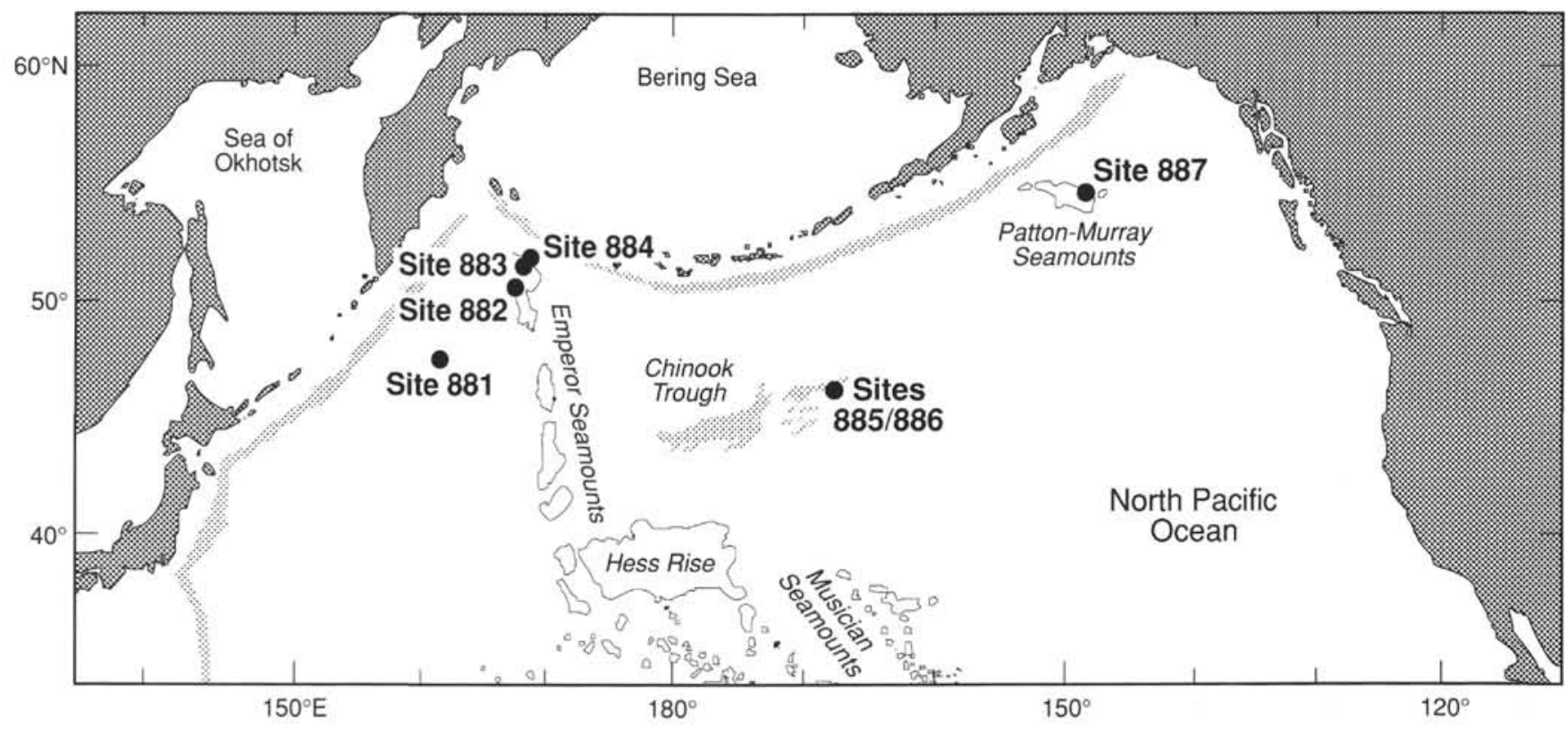

Figure 1. Index map of the North Pacific Ocean showing locations of Leg 145 drill sites.

graphic history of the Northern Hemisphere portion of this late Mesozoic superocean is known. Drilling locations planned for Leg 145 underlay the paleo-North Pacific subtropical gyre and were expected to provide a useful record of that old ocean. The validity of our Cretaceous paleoceanographic reconstructions is only as good as our knowledge of the drill-site paleolocations. This is more of a problem in the North Pacific than elsewhere, because a major plate boundary reorganization occurred during the Late Cretaceous magnetic quiet zone, and the exact nature of that history and ensuing Late Cretaceous and Paleogene plate motions remain a matter of interpretation as of the summer of 1992 (see Rea and Dixon, 1983; Engebretson et al., 1984; Mammerickx and Sharman, 1988). Seafloor ages at two of the Leg 145 drilling locations may further our understanding of the tectonic history of the North Pacific Ocean.

\section{SCIENTIFIC OBJECTIVES}

The goal of Leg 145 was to enhance our understanding of the paleoceanography and paleoclimatology of the North Pacific Ocean. Specifically, we intended to define the following:

1. The high-resolution Neogene record of the sub-Arctic Ocean region,

2. The nature and history of formation of North Pacific Deep Water,

3. The middle Miocene onset of silica deposition (the "silica shift" problem),

4. The Late Cretaceous and Cenozoic records of atmospheric circulation,

5. The Late Cretaceous and Cenozoic records of ocean chemistry,

6. The record of Northern Hemisphere continental climate.

7. The paleoceanography of the late Mesozoic superocean,

8. The tephrochronology of the Kuril and Aleutian arcs, and

9. The age and nature of basement in regions where these are poorly understood.

The discovery of foraminifer-bearing sediments on Detroit Seamount (Keigwin, 1987: Keigwin et al., 1992) and Patton-Murray Seamount (Zahn et al., 1991) in the last few years allow one to apply the techniques of isotope paleoceanography to the subarctic Pacific Ocean. Drilling in these locations was planned along both depth
$(2400-3800 \mathrm{~m})$ and longitudinal $\left(148^{\circ} \mathrm{W}\right.$ to $\left.168^{\circ} \mathrm{E}\right)$ transects in rapidly deposited sediments, resulting in high-resolution paleoceanographic information. Well-constrained temporal control was expected to be provided by all four major fossil groups and by the magnetic reversal stratigraphy of the high-latitude, clay-rich sediments.

The history of organic carbon and opal deposition was expected to reveal detailed records of the activity and productivity of the Oyashio and Alaskan currents, especially the details of the onset of voluminous silica deposition in the North Pacific during the middle Miocene. Continentally derived materials found at these sites (such as ice-rafted debris, hemipelagic mud, and eolian dust) allow us to interpret the nature of continental climate in the respective source regions. Similarly, sections at Sites 881 (NWIA), 882 (DSM-3), 883 (DSM-1), and 887 (PM-1) (Fig. 1) promised to contain a good record of the tephrochronology of the Kuril and Aleutian arcs; some of the ash layers should be datable. Drilling at Site 884 (DSM-4) on the Meiji Tongue, a thick drift deposit prograding south along the eastern side of the Emperor Seamounts (Scholl et al., 1977; Damuth et al., 1983; Mammerickx, 1985) was planned to provide physical and possibly chemical records of bottomwater movement in this portion of the North Pacific Ocean. The Meiji Drift is presumed to be Pliocene-Pleistocene in age, but no data have been available for addressing this question.

The Miocene onset of silica deposition in the North Pacific may have been the result of the establishment of a more modern deep-water circulation, resulting in the transport of nutrient-rich deep waters to the North Pacific and their subsequent upwelling, or of increased vigor of atmospheric circulation, resulting in stronger ocean-surface circulation and thus more biological productivity. Drilling at Sites 881 (NW1A) and $885 / 886$ (NW4A) was expected to allow for the linking of the eolian dust record of atmospheric circulation with the opal record of silica deposition to investigate these questions. In addition, drilling at Site 881 was expected to provide the northernmost site along the north-south transect across the Kuroshio-Oyashio confluence, started by Leg 86 (Sites $578,579,580$, and 591 ), and together those sites should permit evaluation of the latitudinal variability of oceanographic processes. Sites 881 and $885 / 886$ were expected to recover siliceous sediments overlying pelagic clays, which in turn overlie Cretaceous limestones. These three sites are situated more than $10^{\circ} \mathrm{N}$ of locations of existing eolian records and will provide some latitudinal definition of the important events seen elsewhere at the Paleocene/Eocene boundary and associated with the general Neogene intensification of circu- 
lation. The pelagic clays at these sites contain a record of ocean paleochemistry; important paleochemical events occurred in conjunction with the Cretaceous/Tertiary and Paleocene/Eocene boundaries. Further, the Late Cretaceous rifting event responsible for the creation of the Chinook Trough should have left a strong geochemical imprint on the sediments of Site 885 (NW4A).

Lower portions of the section at Sites 881 (NW1A), 883 (DSM-1), and $885 / 886$ (NW4A) were expected to encounter middle to Late Cretaceous limestones and to provide information about the nature of the northern subtropical Pacific Ocean portion of the large Cretaceous superocean. Basement ages at these sites should help us to understand the details of the Cretaceous tectonic evolution of the North Pacific Ocean.

\section{REFERENCES}

Damuth, J.E., Jacobi, R.D., and Hayes, D.E., 1983. Sedimentation processes in the northwest Pacific Basin revealed by the echo-character mapping studies. Geol. Soc. Am. Bull., 94:381-395.

Engebretson, D.C., Cox, A., and Gordon, R.G., 1984. Relative motion between oceanic plates of the Pacific basin. J. Geophys. Res., 89:10291-10310.

Hovan, S.A., Rea, D.K., and Pisias, N.G., 1991. Late Pleistocene continental climate and oceanic variability recorded in northwest Pacific sediments. Paleoceanography: 6:349-370.

Janecek, T.R., 1985. Eolian sedimentation in the Northwest Pacific Ocean: a preliminary examination of the data from Deep Sea Drilling Project Sites 576 and 578. In Heath, G.R., Burckle, L.H., et al., Init. Repts. DSDP. 86 Washington (U.S. Govt. Printing Office), 589-603.

Janecek, T.R., and Rea, D.K., 1983. Eolian deposition in the northeast Pacific Ocean: Cenozoic history of atmospheric circulation. Geol. Soc. Am. Bull.. 94:730-738.

Keigwin, L.D., 1987. North Pacific deep water formation during the latest glaciation. Nature, 330:363-364.

Keigwin, L.D., Jones, G.A., and Froelich, N.P., 1992. A 15,000-year paleoenvironmental record from Meiji seamount, far northwestern Pacific. Earth Planet Sci. Lett., 111:425-440.

Keller, G., and Barron, J.A., 1983. Paleoceanographic implications of Miocene deep-sea hiatuses. Geol. Soc. Am. Bull., 94:590-613.

Kennett, J.P., 1986. Miocene to early Pliocene oxygen and carbon isotope stratigraphy of the Southwest Pacific, DSDP Leg 90. In Kennett, J.P., von der Borch, C.C., et al., Init. Repts. DSDP, 90 (Pt. 2): Washington (U.S Govt. Printing Office), 1383-1411.

Kyte, F.T., and Wasson, J.T., 1986. Accretion rate of extraterrestrial matter: iridium deposited 33 to 67 million years ago. Science, 232:1225-1229.

Leinen, M., 1987. Paleochemical signatures in North Pacific pelagic clays. I: Partitioning experiments. Geochim. Cosmochim. Acta. 51:305-320. , 1989. The pelagic clay province of the North Pacific Ocean. In Winterer, E.L., Hussong, D.M., and Decker, R.W. (Eds.), The Geology of North America (Vol. N): The Eastern Pacific Ocean and Hawaii. Geol. Soc. Am., 323-335.
Mammerickx, J., 1985. A deep-sea thermohaline flow path in the northwest Pacific. Mar. Geol., 65:1-19.

Mammerickx, J., and Sharman, G.F., 1988. Tectonic evolution of the North Pacific during the Cretaceous quiet period. J. Geophys. Res., 93:3009-3024.

Owen, R.M., and Rea, D.K., 1985. Sea-floor hydrothermal activity links climate to tectonics; the Eocene $\mathrm{CO}_{2}$ greenhouse. Science, 227:166-169.

Rea, D.K., and Dixon, J.M., 1983. Late Cretaceous and Paleogene tectonic evolution of the North Pacific Ocean. Earth Planet. Sci. Lett., 65:145-166.

Rea, D.K., Leinen, M., and Janecek, T.R., 1985. A geological approach to the long-term history of atmospheric circulation. Science, 227:721-725.

Rea, D.K., and Schrader, H., 1985. Late Pliocene onset of glaciation: ice rafting and diatom stratigraphy of North Pacific DSDP cores. Palaeogeogr. Palaeoclimatol., Palaeoecol., 49:313-325.

Rea, D.K., Zachos, J.C., Owen, R.M., and Gingerich, P.D., 1990. Global change at the Paleocene-Eocene boundary: climatic and evolutionary consequences of tectonic events. Palaeogeogr., Palaeoclimatol., Palaeoecol., 79:117-128.

Ruddiman, W.F., Raymo, M.E., Martinson, D.G., Clement, B.M., and Backman, J., 1989. Pleistocene evolution: Northern Hemisphere ice sheets and North Atlantic Ocean. Paleoceanography, 4:353-412.

Savin, S.M., Douglas, R.G., Keller, G., Killingley, J.S., Shaughnessy, L., Sommer, M.A., Vincent, E., and Woodruff, F., 1981. Miocene benthic foraminiferal isotope records: a synthesis. Mar. Micropaleontol., 6:423-450.

Scholl, D.V., Hein, J.R., Marlow, M., Buffington, E.C., 1977. Meiji sediment tongue: North Pacific evidence for limited movement between the Pacific and North American plates. Geol. Soc. Am. Bull., 88:1567-1576.

Shackleton, N.J.. Backman. J., Zimmerman, H., Kent, D.V., Hall, M.A., Roberts, D.G., Schnitker, D., Baldauf, J.G., Desprairies, A., Homrighausen. R., Huddlestun, P., Keene, J.B., Kaltenback, A.J.. Krumsiek, K.A.O., Morton, A.C., Murray, J.W., and Westberg-Smith, J., 1984. Oxygen isotope calibration of the onset of ice-rafting and history of glaciation in the North Atlantic region. Nature, 307:620-623.

Woodruff, F., and Savin, S.M., 1989. Miocene deepwater oceanography. Paleoceanography, 4:87-140.

Woodruff, F., Savin, S.M., and Douglas, R.G., 1981. Miocene stable isotope record: a detailed deep Pacific Ocean study and its paleoclimatic implications. Science, 212:665-668.

Zahn, R., Pedersen, T.F., Bornhold, B.D., and Mix, A.C., 1991, Water mass conversion in the glacial subarctic Pacific $\left(54^{\circ} \mathrm{N}, 148^{\circ} \mathrm{W}\right)$ : physical constraints and the benthic-planktonic stable isotope record. Paleoceanography, 6:543-560.

\footnotetext{
* Abbreviations for names of organizations and publication titles in ODP reference lists follow the style given in Chemical Abstracts Service Source Index (published by American Chemical Society).
}

\section{Ms 145IR-103}

